\title{
Correction to: Structure and Raman spectra of binary barium phosphate glasses
}

\author{
Branislav Hruška ${ }^{1} \cdot$ Rajesh Dagupati $^{1}$ - Mária Chromčíkováa ${ }^{2,3}$ - Aleksandra Nowicka ${ }^{1}$ Jaroslava Michálková ${ }^{1}$. \\ Jacob A. Peterson ${ }^{1} \cdot$ Marek Liška $^{2,3} \cdot$ Francisco Munoz ${ }^{4}$
}

Published online: 19 March 2020

(c) The Author(s) 2020

\section{Correction to: Journal of Thermal Analysis and Calorimetry https://doi.org/10.1007/s10973-020-09328-0}

The article Structure and Raman spectra of binary barium phosphate glasses, written by Branislav Hruška, Rajesh Dagupati, Mária Chromčíková, Aleksandra Nowicka, Jaroslava Michálková, Jacob A. Peterson, Marek Liška, and Francisco Munoz, was originally published electronically on the publisher's internet portal on January 27, 2020, without open access. With the author(s)' decision to opt for Open Choice, the copyright of the article changed on March 21, 2020, to @ The Author(s) 2020 and the article is forthwith distributed under a Creative Commons Attribution 4.0 International License (https://creativecommons.org/licenses/ by/4.0/), which permits use, sharing, adaptation, distribution, and reproduction in any medium or format, as long as you give appropriate credit to the original author(s) and the source, provide a link to the Creative Commons license, and indicate if changes were made.

The original article has been corrected.

Open Access This article is licensed under a Creative Commons Attribution 4.0 International License, which permits use, sharing, adaptation, distribution and reproduction in any medium or format, as long as you give appropriate credit to the original author(s) and the source,

The original article can be found online at https://doi.org/10.1007/ s10973-020-09328-0.

Branislav Hruška

branislav.hruska@tnuni.s

1 FunGlass, Alexander Dubček University of Trenčín, Študentská 2, 91150 Trenčín, Slovakia

2 VILA - Joined Glass Centre of the IIC SAS, TnUAD, FChPT STU, Študentská 2, 91150 Trenčín, Slovakia

3 Institute of Inorganic Chemistry of Slovak Academy of Sciences, Dúbravská cesta 9, 84536 Bratislava, Slovakia

4 Institute of Ceramics and Glass (CSIC), Kelsen 5, 28049 Madrid, Spain provide a link to the Creative Commons licence, and indicate if changes were made. The images or other third party material in this article are included in the article's Creative Commons licence, unless indicated otherwise in a credit line to the material. If material is not included in the article's Creative Commons licence and your intended use is not permitted by statutory regulation or exceeds the permitted use, you will need to obtain permission directly from the copyright holder. To view a copy of this licence, visit http://creativecommons.org/licenses/by/4.0/.

Publisher's Note Springer Nature remains neutral with regard to jurisdictional claims in published maps and institutional affiliations. 